\title{
Annual Change of Reproductive Hormones in Female Angora Goats
}

\author{
Erkan Pehlivan $^{1 *}$, Hüseyin Polat $^{2}$, Gürsel Dellal $^{1}$ \\ ${ }^{1}$ Department of Animal Science, Faculty of Agriculture, Ankara University, 06110 Ankara, Turkey \\ ${ }^{2}$ Department of Biotechnology and Molecular Biology, Faculty of Science and Letters, Aksaray University, 68100 Aksaray, Turkey \\ A R T I C LE I N F O \\ Research Article \\ Received 09 March 2017 \\ Accepted 29 March 2017 \\ Keywords: \\ Angora goat \\ Reproduction hormones \\ Annual change \\ Photoperiod \\ Seasonality \\ *Corresponding Author: \\ E-mail: pehlivan@agri.ankara.edu.tr \\ A B S T R A C T \\ In this research, annual changes of melatonin, gonadotropin-releasing hormone, follicle \\ stimulating hormone, luteinizing hormone, estrogen, testosterone and progesterone were \\ studied on 6 heads of 1.5 years old female Angora goat. To determine hormones \\ concentrations, blood samples were taken from jugular vein of each goat in every month \\ for a year. The blood samples were centrifuged at 4000xg for $5 \mathrm{~min}$. and serum was \\ stored at $-20^{\circ} \mathrm{C}$ until analyses time. Hormones analyses in the serum were performed by \\ enzyme immunoassay (EIA) method. Monthly climatic values and photoperiod were \\ obtained from the Turkish State Meteorological Service and temperature-humidity index \\ was calculated with climatic values. In the study, in order to determine any possible \\ differences in the observed hormones concentrations with respect to months, repeated \\ measures ANOVA analysis was performed. As a result of statistical analysis, there were \\ no significant differences among the months for gonadotropin-releasing hormone, follicle \\ stimulating hormone and testosterone concentration, while significant differences were \\ found among the months for melatonin, luteinizing hormone and progesterone, and \\ estrogen concentration in female Angora goats. According the results of this study, could \\ be concluded that the releases of reproductive hormones examined in female Angora \\ goats was seasonally dependent.
}

\section{Introduction}

Reproduction is the most important process in production of farm animals because of it forms the basis for production economically products such as meat, milk and fiber. Reproduction activity is seasonal in small ruminants raised at subtropical temperate and regions (Delgadillo et al., 1999). The most important environmental factor affecting the seasonal reproduction dependence in small ruminants is the annual change in day length (photoperiod). (Zarazaga et al., 2010; Fatet et al., 2011, Abecia et al., 2012).

Photoperiodic control of female goat's reproduction is achieved by the circadian rhythm release of melatonin hormone by the pineal gland. Gonadotropin-releasing hormone $(\mathrm{Gn}-\mathrm{RH})$ releases from the hypothalamus is induced by the increase in secretion of melatonin from the pineal gland and it causes the release of follicle stimulating hormone (FSH) and luteinizing hormone (LH) from the anterior lob of pituitary gland. FSH is functional in folliculogenesis and heat increasing the release of estrogen, while LH provides the ovulation. The seasonal dependence of reproductive hormones in female goats is not usually seen in male goats and their sperm production and libido functions continue throughout the year. (Hafez, 1974; Chemineau et al., 1988; Chemineau et al., 1992; Malpaux et al., 1994).
Determination of hormonal changes in farm animals reflects the animal physiological stages and provides important information about the production processes, such as reproduction, growth and lactation. Changes in the reproductive hormones concentrations in different physiological periods are among of the most important physiological parameters to determine the fertility status of female goats (Talebi et al., 2012).

Mohair, used by textile industry as animal fiber, is produced only by Angora goats in the world. An effective and profitable mohair production depends of a good management of raising periods, such as mating, pregnancy, kidding, lactation, growth, feeding and shearing. The good management practice is directly related with the knowing and directing of the basic animal physiological parameters. Compared with other goat breeds, there are not enough studies on annual changes of reproductive hormones in Angora goats. Therefore, in this study changes in reproductive hormones were determined within a period of one year, including different physiological periods and relationship between these changes and seasonal factors, such as temperaturehumidity index and photoperiod was emphasized in female Angora goats. 


\section{Materials and Methods}

Experimental Animals, Location and Management

This study was conducted on 6 heads young female Angora goat (1.5 years old) that mean weighing $23.71 \pm 1.51 \mathrm{~kg}$ at the beginning of the experiment, for one year (from December of 2010 to November of 2011) at the Animal Husbandry Station (39 57'42.5" north latitude, $32^{\circ} 51^{\prime} 56.2^{\prime \prime}$ east longitude) at the Ankara University, Faculty of Agriculture, Department of Animal Science. All the goats were clinically healthy and free from internal and external parasites. They were housed as single gender group in shaded outdoor pen except during mating period (September and October). Kiddings were occurred in March. Kids were kept together with their mother during lactation period and the goats were not milking during this period. The goats were fed with wheat straw, alfalfa hay, maize silage and grains concentrate (in some physiological periods). Fresh water was always available. Management of the experimental animals had not intervened in the general operation of the station.

\section{Blood Collection and Hormones Analyses}

The blood samples were taken regularly from the jugular vein of each goat into vacuum tubes without anticoagulant (VACUETTE ${ }^{\circledR}$ TUBE $9 \mathrm{ml} \mathrm{Z} \mathrm{Serum} \mathrm{Clot}$ Activator) in every month during one whole year. The blood samples were centrifuged at 4000xg for $5 \mathrm{~min}$ and the serum was stored at $-20^{\circ} \mathrm{C}$ until analyses time. Melatonin, Gn-RH, FSH, LH and estrogen (Cusabio, China), and testosterone and progesterone (DRG, USA) hormones were determined in the blood serum using commercial ELISA kits. The minimum detectable concentrations were $1.56 \mathrm{pg} / \mathrm{ml}, 1.25 \mathrm{pg} / \mathrm{ml}, 20 \mu \mathrm{IU} / \mathrm{ml}$, $0.12 \mu \mathrm{IU} / \mathrm{ml}, 20 \mathrm{pg} / \mathrm{ml}, 0.083 \mathrm{ng} / \mathrm{ml}$, and $0.045 \mathrm{ng} / \mathrm{ml}$ for melatonin, Gn-RH, FSH, LH, estrogen, testosterone and progesterone hormones, respectively.

Climatic Values, Temperature-Humidity Index (THI) and Photoperiod

Climatic values and photoperiod were obtained from the Turkish State Meteorological Service (TSMS, 2011) in order to estimate the severity of heat stress during the experimental period. Temperature-humidity index (THI) were calculated using the equation below reported by Marai et al. (2001) for sheep and goats (Marai et al. 2007). Average for climatic values, THI and photoperiod are shown in Table 1.

$$
\text { "THI }=\mathrm{db}^{\circ} \mathrm{C}-\left\{(0.31-0.31 \mathrm{RH} / 100)\left(\mathrm{db}{ }^{\circ} \mathrm{C}-14.4\right)\right\} "
$$

Where $\mathrm{db}^{\circ} \mathrm{C}$ is the dry bulb temperature $\left({ }^{\circ} \mathrm{C}\right)$ and $\mathrm{RH}$ is the relative humidity $(\mathrm{RH} \%) / 100$. The values obtained indicate the following: $<22.2=$ absence of heat stress; 22.2 to $<23.3=$ moderate heat stress: 23.3 to $<25.6=$ severe heat stress and 25.6 and more $=$ extreme severe heat stress (Marai et al. 2007).

\section{Statistical Analysis}

In the study, in order to determine any possible differences in the observed hormones concentrations with respect to months, repeated measures ANOVA analysis was performed. Duncan multiple comparison test was utilized to determine the differences among months. The SPSS18 and MSTAT-C statistical software programs were used for the variance analysis and Duncan multiple comparison tests, respectively (Gürbüz et al., 2003).

\section{Results}

In this research, the average of monthly values for serum melatonin, Gn-RH, FSH, LH, estrogen, testosterone and progesterone hormones concentration on female Angora goat are showed in Table 2. As a result of statistical analysis, there were no significant differences among the months for Gn-RH, FSH and testosterone concentrations $(\mathrm{P}>0.05)$, while significant differences were found among the months for melatonin, $\mathrm{LH}$, progesterone $\quad(\mathrm{P}<0.01), \quad$ and estrogen $\quad(\mathrm{P}<0.05)$ concentrations in blood serum of Angora goats.

The THI level is the lowest in February, a continuous increase was observed from this point and reached its highest level in August, while it showed a gradual decrease from August to January (Figure 1). Photoperiod showed similar trend with THI, however it increased from December to June and decreased from June.

Table 1 Average climatic values, THI and photoperiod during the experimental period

\begin{tabular}{l|cccc}
\hline \multicolumn{1}{c}{ Months } & Average temperature $\left({ }^{\circ} \mathrm{C}\right)$ & Average humidity $(\%)$ & THI & Photoperiod (hour:min) \\
\hline December & 11.4 & 75.3 & 11.63 & $9: 40$ \\
January & 0.2 & 67.3 & 1.64 & $9: 45$ \\
February & -0.3 & 67.6 & 1.18 & $10: 37$ \\
March & 5.4 & 87.5 & 5.75 & $11: 56$ \\
April & 9.7 & 58.3 & 10.31 & $13: 10$ \\
May & 9.4 & 52.8 & 10.13 & $14: 16$ \\
June & 20.8 & 53.6 & 19.88 & $14: 40$ \\
July & 22.8 & 52.1 & 21.55 & $14: 33$ \\
August & 29.1 & 43.9 & 26.54 & $13: 38$ \\
September & 21.8 & 45.9 & 20.56 & $12: 23$ \\
October & 11.8 & 55.7 & 12.16 & $11: 18$ \\
November & 5.9 & 71.9 & 6.64 & $10: 12$ \\
\hline
\end{tabular}


Table 2 Average of monthly concentrations of serum melatonin, GnRH, FSH, LH, estrogen, testosterone, and progesterone hormones on female Angora goat $\left(\bar{X} \pm S_{X}\right)$.

\begin{tabular}{l|ccccccc}
\hline \multicolumn{1}{c|}{ Months } & $\begin{array}{c}\text { Melatonin } \\
(\mathrm{pg} / \mathrm{ml})\end{array}$ & $\begin{array}{c}\mathrm{GnRH} \\
(\mathrm{pg} / \mathrm{ml})\end{array}$ & $\begin{array}{c}\text { FSH } \\
(\mu \mathrm{IU} / \mathrm{ml})\end{array}$ & $\begin{array}{c}\mathrm{LH} \\
(\mu \mathrm{IU} / \mathrm{ml})\end{array}$ & $\begin{array}{c}\text { Estrogen } \\
(\mathrm{pg} / \mathrm{ml})\end{array}$ & $\begin{array}{c}\text { Testosterone } \\
(\mathrm{ng} / \mathrm{ml})\end{array}$ & $\begin{array}{c}\text { Progesterone } \\
(\mathrm{ng} / \mathrm{ml})\end{array}$ \\
\hline December & $9.25 \pm 0.84^{\mathrm{b}}$ & $10.44 \pm 1.47$ & $243.00 \pm 28.90$ & $13.91 \pm 5.61^{\mathrm{a}}$ & $126.70 \pm 16.40^{\mathrm{c}}$ & $0.17 \pm 0.02$ & $18.34 \pm 4.22^{\mathrm{a}}$ \\
January & $9.35 \pm 0.93^{\mathrm{b}}$ & $10.29 \pm 0.97$ & $237.30 \pm 12.90$ & $12.00 \pm 2.59^{\mathrm{ab}}$ & $128.80 \pm 10.60^{\mathrm{bc}}$ & $0.16 \pm 0.03$ & $18.52 \pm 2.92^{\mathrm{a}}$ \\
February & $11.85 \pm 0.94^{\mathrm{a}}$ & $9.91 \pm 1.12$ & $232.30 \pm 17.80$ & $9.07 \pm 1.85^{\mathrm{abc}}$ & $129.20 \pm 14.50^{\mathrm{c}}$ & $0.17 \pm 0.03$ & $10.56 \pm 1.48^{\mathrm{b}}$ \\
March & $11.58 \pm 1.24^{\mathrm{a}}$ & $10.61 \pm 1.62$ & $249.00 \pm 33.70$ & $7.25 \pm 1.67^{\mathrm{bcd}}$ & $208.50 \pm 35.00^{\mathrm{a}}$ & $0.23 \pm 0.04$ & $5.03 \pm 2.24^{\mathrm{c}}$ \\
April & $10.00 \pm 0.98^{\mathrm{ab}}$ & $9.25 \pm 1.36$ & $221.50 \pm 31.00$ & $3.36 \pm 1.06^{\mathrm{cd}}$ & $142.30 \pm 25.30^{\mathrm{bc}}$ & $0.17 \pm 0.03$ & $1.30 \pm 0.17^{\mathrm{c}}$ \\
May & $7.80 \pm 0.28^{\mathrm{bc}}$ & $7.63 \pm 0.07$ & $233.80 \pm 23.10$ & $2.20 \pm 0.19^{\mathrm{d}}$ & $156.20 \pm 19.10^{\mathrm{abc}}$ & $0.14 \pm 0.02$ & $1.09 \pm 0.01^{\mathrm{c}}$ \\
June & $7.74 \pm 0.25^{\mathrm{bc}}$ & $8.41 \pm 0.40$ & $205.50 \pm 18.00$ & $3.04 \pm 0.38^{\mathrm{d}}$ & $160.17 \pm 9.93^{\mathrm{abc}}$ & $0.15 \pm 0.03$ & $1.11 \pm 0.03^{\mathrm{c}}$ \\
July & $6.90 \pm 0.37^{\mathrm{c}}$ & $9.03 \pm 0.78$ & $210.70 \pm 22.10$ & $2.67 \pm 0.46^{\mathrm{d}}$ & $148.80 \pm 20.80^{\mathrm{bc}}$ & $0.25 \pm 0.05$ & $1.11 \pm 0.02^{\mathrm{c}}$ \\
August & $6.62 \pm 0.35^{\mathrm{c}}$ & $8.16 \pm 0.39$ & $245.00 \pm 41.90$ & $2.49 \pm 0.35^{\mathrm{d}}$ & $144.80 \pm 21.50^{\mathrm{bc}}$ & $0.15 \pm 0.03$ & $1.10 \pm 0.01^{\mathrm{c}}$ \\
September & $6.77 \pm 0.41^{\mathrm{c}}$ & $8.88 \pm 0.65$ & $291.30 \pm 31.60$ & $2.24 \pm 0.17^{\mathrm{d}}$ & $196.70 \pm 20.20^{\mathrm{ab}}$ & $0.13 \pm 0.01$ & $1.09 \pm 0.01^{\mathrm{c}}$ \\
October & $8.24 \pm 0.30^{\mathrm{bc}}$ & $7.67 \pm 0.23$ & $237.20 \pm 14.90$ & $2.64 \pm 0.12^{\mathrm{d}}$ & $155.30 \pm 17.30^{\mathrm{abc}}$ & $0.16 \pm 0.02$ & $1.12 \pm 0.02^{\mathrm{c}}$ \\
November & $8.48 \pm 0.80^{\mathrm{bc}}$ & $8.18 \pm 0.29$ & $208.20 \pm 16.40$ & $4.93 \pm 1.26^{\mathrm{cd}}$ & $112.20 \pm 17.70^{\mathrm{c}}$ & $0.13 \pm 0.01$ & $4.03 \pm 1.69^{\mathrm{c}}$ \\
P value & 0.000 & 0.155 & 0.541 & 0.000 & 0.022 & 0.072 & 0.000 \\
\hline
\end{tabular}

The melatonin concentration increased $(\mathrm{P}<0.01)$ from December to February and it decreased $(\mathrm{P}<0.01)$ gradually from February to August and then increased again from this month. The Gn-RH concentration linearly decreased from December to May, except for a peak concentration in March. After May had a slight increase until July and there was a fluctuation from July to November in Gn-RH concentration. Was observed a fluctuation from December to June in FSH concentration and from July there was a sharp increase until September. From September to November decreased FSH concentration.

LH concentration showed a dramatic decline $(\mathrm{P}<0.01)$ from December to May, reaching the lowest concentration, and it increased from May to October and a sharp increase occurred from October to December (Figure 2). The serum estrogen and testosterone concentration generally fluctuated throughout the year, except for two high concentrations in March and September $(\mathrm{P}<0.01)$ and March and July, respectively. Serum progesterone concentration were higher between December and January, but decreased significantly $(\mathrm{P}<0.01)$ from January to April and these values followed an almost constant trend between April and October, and a sharp increase occurred after October.

\section{Discussion}

The onset and length of the mating season in goats is dependent of several factors, such as latitude, climate, breed, physiological stage, presence of a male, nutritional status, management system, and photoperiod. However, the main environmental factor affecting seasonal reproduction in goats is the photoperiod (Dellal and Cedden, 2002; Fatet et al., 2011). Seasonality is observed in most breeds of goats raised from high latitudes $\left(>35^{\circ}\right)$, in some local breeds from subtropical latitudes $\left(25-35^{\circ}\right)$, and in temperate regions the mating period is observed in the fall and winter seasons (Chemineau et al., 1992; Fatet et al., 2011; González-Flores et al., 2017). Similarly, the breeding season of Angora goats raised in Ankara, Turkey, varies between September and November (Özdemir, 2009). Thus, melatonin concentration starts to increase from the beginning of the breeding season and its concentration decreases towards the end of the breeding season (Figure 1). The reproductive photoperiod control patterns are mediated through circadian rhythmic secretions of melatonin by the pineal gland during darkness periods (Alila-Johansson et al., 2001; Fatet et al., 2011; González-Flores et al., 2017). Indeed, the melatonin concentration detected in this study was increased dramatically during the gestation period (the darkest period) and had started decreasing in kidding period and had reached the lowest concentration in the end of the lactation period. Data related to melatonin hormone observed in this study are in harmony with the findings obtained in sheep and goat breeds (Dicks, 1994; Gebbie et al., 1994; Malpaux et al., 1994; Gebbie et al., 1999; Fatet et al., 2011; Bartlewski et al., 2011).

The majority of female sheep and goat breeds that are being raised in the northern and southern hemispheres, a seasonal anestrus has been shown in the period from birth to mating seasons generally includes spring and summer (Fatet et al., 2011). Seasonal anestrus also includes anestrus processes linked to lactation and postpartum (Dellal and Cedden 2002; González-Flores et al., 2017). Indeed, no significant difference was observed in the seasonal anestrus period in terms of the hormonal results obtained in this study. The main differences occurred from the beginning of the mating period and the end of the kidding period. As a matter of fact, concentrations of $\mathrm{Gn}-\mathrm{RH}, \mathrm{FSH}$ and $\mathrm{LH}$ in the reproductive season determined in this study were found to be higher than concentrations in seasonal anestrus period. In goats, as well as in sheep and deer, the hypothalamus secretion of the Gn-RH begins to increase before the onset of the mating season. Increased Gn-RH concentration is caused due FSH and LH release from the anterior lob of pituitary gland, which is needed for follicular development and for the onset of ovulation. Similar findings regarding the $\mathrm{Gn}$ $\mathrm{RH}, \mathrm{FSH}$, and LH concentrations were also obtained from researches performed in different goat breeds (Hafez, 1974; Bono et al., 1983; Chemineau et al., 1988; Chemineau et al., 1992; Malpaux et al., 1994; Błaszczyk et al., 2004). 
THI and Photoperiod

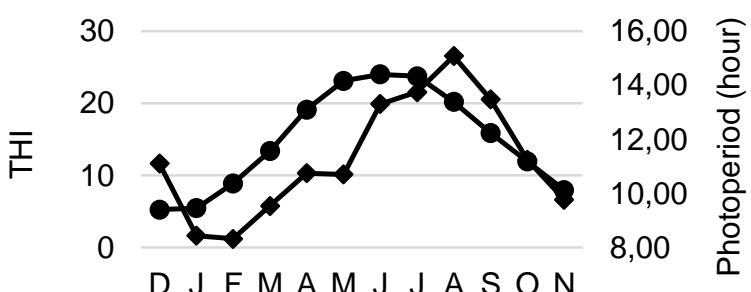
Months

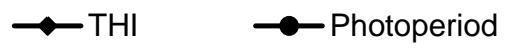

$\mathrm{GnRH}$

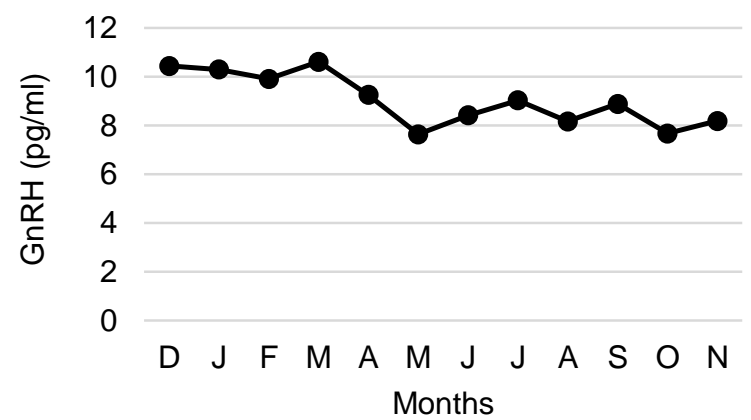

Melatonin

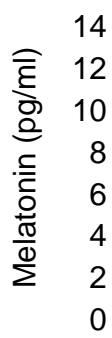

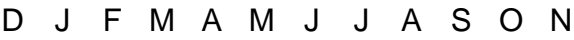
Months

$\mathrm{FSH}$

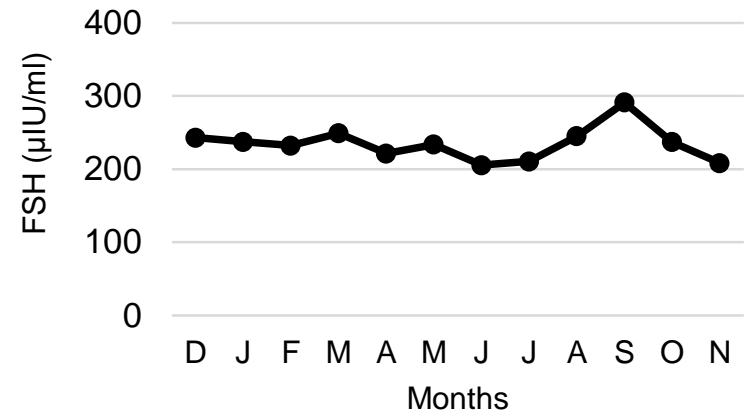

Figure 1 Annual profile of the THI and photoperiod, melatonin, GnRH, and FSH hormones concentration on female Angora goat.

$\mathrm{LH}$

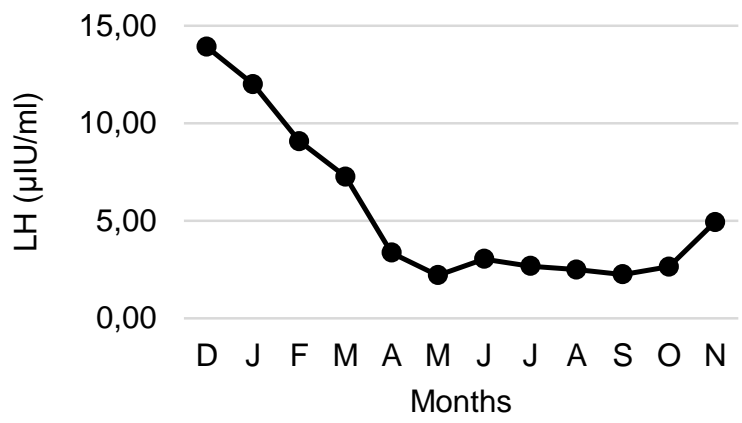

Testosterone

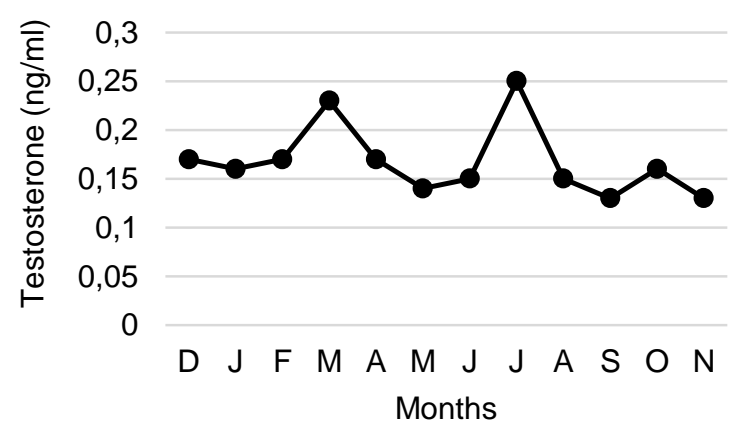

Estrogen

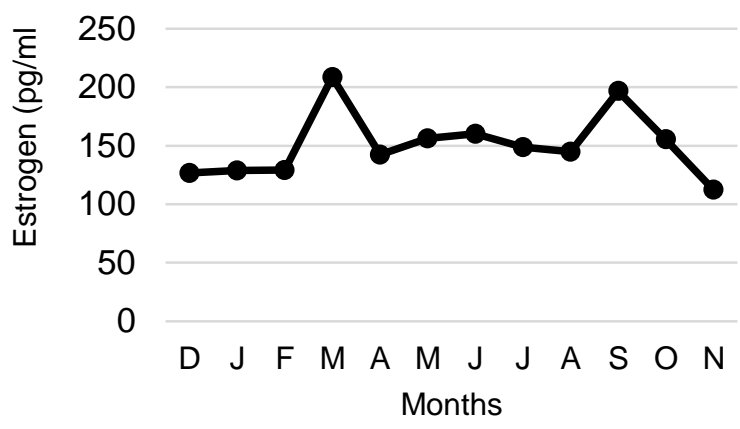

Progesterone

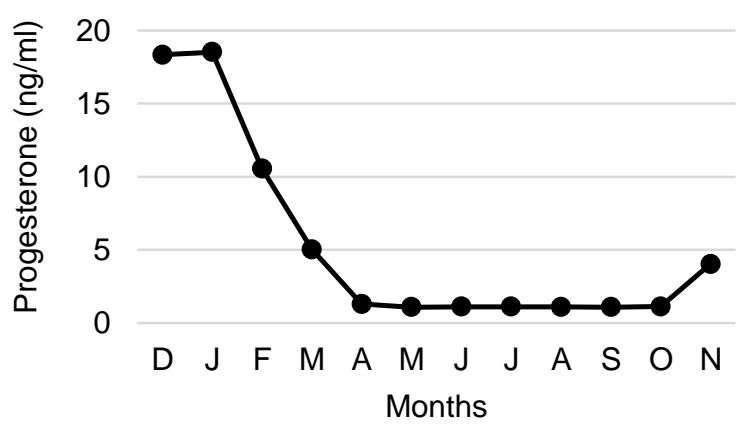

Figure 2 Annual profile of the LH, estrogen, testosterone, and progesterone hormones concentration on female Angora goat. 
Estrogen is a steroidal hormone produced by graff cells in the follicles on females of mammalian animals. The essential function of the estrogen in females is on the reproductive canals and mammary glands, and in these organs, it stimulates the growth and proliferation of the cells and provides the development and continuity of female sexual characteristics (Hafez, 1974; Y1lmaz, 1999). Indeed, the findings related to the annual change in estrogen hormone obtained this study support these functions. As a matter of fact, two peak of estrogen concentrations were observed in this study. The first high estrogen concentration was seen in March that is the last month of pregnancy. Mammary gland in goats has the maximum development during the last month of pregnancy (Anderson et al., 1981). Therefore, the maximum concentration of estrogen in March is due the development of the mammary gland in the goats. The other peak of estrogen concentration in female goats was observed in September. September is the beginning of the mating season for female Angora goats (Özdemir, 2009). Estrogen is the main hormone that acts in the appearance of behavioral heat in female mammalians. And also, all trends of change in estrogen in this study are in harmony with the findings from other studies on Angora and other goat breeds (Bono et al., 1983; Alaçam et al., 1999; Blaszczyk et al., 2004; Khanum et al., 2008; Talebi et al., 2012).

In female mammals, testosterone is secreted by the ovaries and adrenals and it can promote female sexual behavior (Hafez, 1974; Y1lmaz, 1999; González-Flores et al., 2017). Although there was no significant difference the testosterone concentration observed in this study, there were two high concentrations, one in the kidding period and another before the mating season. In general, the trend of the testosterone is similar to that of the estrogen. Because, testosterone act as precursor for estrogen synthesis in the granulosa cells in females (Sanderson 2006). However, were not find another study conducted in female goats to compare these results obtained from female Angora goats.

The main role of progesterone in female goats is to continue their pregnancy (Hafez, 1974; Y1lmaz, 1999). Alaçam et al., (1999) reported that the preservation and maintenance of pregnancy in goats was carried out entirely by the progesterone released from the corpus luteum, unlike of other ruminants. As a matter of fact, findings obtained from this study support this. When Figure 1 is examined, the progesterone concentrations in female goats increase until the first half of pregnancy and then its concentration was decreased rapidly and has reached basal level after kidding. Similar results were obtained in other studies conducted to determine the progesterone concentration in goats during pregnancy (Bono et al., 1983; Kadzere et al., 1997; Gaafar et al., 2005; Khanum et al., 2008; Sogerescu et al., 2012; Talebi et al., 2012).

\section{Acknowledgement}

The study was supported by Ankara University Scientific Research Projects Directorate through project BAP-09B4347010: The Annual Change of Hormonal, Hematologic and Biochemical Blood Parameters in Angora Goats, 2009-2013.

\section{References}

Abecia JA, Forcada F, Gonzalez-Bulnes A. 2012. Hormonal control of reproduction in small ruminants. Animal Reproduction Science 130: 173-179.

Alaçam E, Güven B, Ayar A, Saban E. 1999. Effect of gonadoreline administration on blood progesterone, oestradiol $17 \beta$ concentration and some fertility parameters in Angora goats. Tr. J. of Veterinary and Animal Sciences 23: 77-81.

Alila-Johansson A, Eriksson L, Soveri T, Laakso ML. 2001. Seasonal variation in endogenous serum melatonin profiles in goats: A difference between spring and fall? Journal of Biological Rhythms (16)2: 254-263.

Anderson RR, Harnes JR, Snead AF, Salah MS. 1981. Mammary growth pattern in goats during pregnancy and lactation. J Dairy Sci. 64: 427-432.

Bartlewski PM, Baby TE, Giffin JL. 2011. Reproductive cycle of sheep. Animal Reproduction Science, 124(3-4): 259-268.

Błaszczyk B, Udała J, Gaczarzewicz D. 2004. Changes in estradiol, progesterone, melatonin, prolactin and thyroxine concentrations in blood plasma of goats following induced estrus in and outside the natural breeding season. Small Ruminant Research 51: 209219.

Bono G, Cairoli F, Tamanini C, Abrate L. 1983. Progesterone, estrogen, LH, FSH and PRL concentrations in plasma during the estrous cycle in goat. Reprod. Nutr. Develop. 23(2A): 217222.

Chemineau P, Malpaux B, Delgadillo JA, Guerin Y, Ravault JP, Thimonier J, Pelletier J. 1992. Control of sheep and goat reproduction: Use of light and melatonin. Anim. Reprod. Sci. 30: 157-184.

Chemineau P, Pelletier J, Guerin Y, Colas G, Ravault JP, Toure G, Almeida G, Thimonier J, Ortovant R. 1988. Photoperiodic and melatonin treatments for the control of seasonal reproduction in sheep and goats. Reprod. Nutr. Develop. 28(2B): 409-422.

Delgadillo JA, Canedo GA, Chemineau P, Guillaume D, Malpaux B, 1999. Evidence for an annual reproductive rhythm independent of foot availability in male Creole Goats in subtropical northern Mexico. Theriogenology 52(4): 727-737.

Dellal G, Cedden F. 2002. Seasonality of reproduction and reproduction and photoperiod relationships in sheep and goat. Hayvansal Üretim 43(1): 64-73 (in Turkish).

Dicks P. 1994. The role of prolactin and melatonin in regulating the timing of the spring moult in the Cashmere goat. European Fine Fiber Network, Occasional Publication No. 2.

Gürbüz F, Baspinar E, Camdeviren H, Keskin S. 2003. Analysis of the repeated measurement experiments. Yüzüncü Y1l University Publications, Van, Turkey (in Turkish).

Fatet A, Pellicer-Rubio MT, Leboeuf B. 2011. Reproductive cycle of goats. Animal Reproduction Science 124(3-4): 211-219.

Gaafar KM, Gabr MK, Teleb DF. 2005. The hormonal profile during the estrous cycle and gestation in Damascus goats. Small Ruminant Research 57: 85-93.

Gebbie FE, Forsyth IA, Arendt J. 1994. Effects of melatonin, bromocriptine and altered light/temperature patterns on coat growth in dairy goats. European Fine Fiber Network, Occasional Publication No. 2. 
Gebbie FE, Forsyth IA, Arendt J. 1999. Effects of maintaining solstice light and temperature on reproductive activity, coat growth, plasma prolactin and melatonin in goats. Journal of Reproduction Fertility 116: 25-33.

González-Flores O, Hoffman KL, Delgadillo JA, Keller M, Paredes RG. 2017. Female sexual behavior in rodents, lagomorphs, and goats. Hormones, Brain, and Behavior 3(1): 59-82.

Hafez ESE. 1974. Reproduction in Farm Animals. In Reproductive Life Cycle. Lea and Febriger, Philadelphia.

Kadzere CT, Llewelyn C.A, Chivandi E. 1997. Plasma progesterone, calcium, magnesium and zinc concentrations from estrous synchronization to weaning in indigenous goats in Zimbabwe. Small Rumin. Res. 24: 21-26.

Khanum SA, Hussain M, Kausar R. 2008. Progesterone and estradiol profiles during estrous cycle and gestation in dwarf goats (Capra Hircus). Pakistan Vet. J. 28(1): 1-4.

Malpaux B, Viguie C, Ravault JP, Thiery JC, Chemineau P. 1994. Photoperiodic and neuroendocrine control of seasonal reproductive functions in the ovine and caprine species. European Fine Fiber Network, Occasional Publication No: 2.

Marai IFM, Ayyat MS, Abd El-Monem UM. 2001. Growth performance and reproductive traits at first parity of New Zealand White female rabbits as affected by heat stress and its alleviation under Egyptian conditions. Trop. Anim. Health and Prod. 33: 451-462.
Marai IFM, El-Darawany AA, Fadiel A, Abdel-Hafez MAM. 2007. Physiological traits as affected by heat stress in sheep-a review. Small Rumin. Res. 71: 1-12.

Özdemir H. 2009. The structural and breeding characteristics of Angora goat rearing in Turkey. PhD thesis (unpublished). Deptt. of Animal Sci., Univ. Ankara, Turkey (in Turkish).

Sanderson JT. 2006. The steroid hormone biosynthesis pathway as a target for endocrine-disrupting chemicals. Toxicological Sciences 94(1): 3-21.

Sogerescu E, Zamfirescu S, Anghel AH, Nadalu D, Rosoiu N. 2012. Seasonal variations of progesterone level and characteristics of breeding season and anoestrus period and Carpathian goats. Journal of Animal and Veterinary Advances 11(9): 1472-1477.

Talebi J, Moghaddam A, Souri M, Mirmahmoudi R. 2012. Steroid hormone profile of Markhoz does (Iranian Angora) throughout estrous cycle and gestation period. Trop. Anim. Health Prod. 44: $355-360$.

TSMS. 2011. Turkish State Meteorological Service, Ankara (Turkey).

Yilmaz B. 1999. Hormones and reproductive physiology. Feryal Press, Ankara, Turkey (in Turkish).

Zarazaga LA, Celi I, Guzmán JL, Malpaux B. 2010. Melatonin concentrations in the two jugular veins, and relationship with the seasonal reproductive activity in goats. Theriogenology 74 : 221-228. 